\section{P144 POTENTIAL REVERSIBLE CAUSES FOR FATIGUE IN SLE PATIENTS - DIFFERENCES BETWEEN MILD AND SEVERE FATIGUE}

Christina Düsing, Gamal Chehab, Jutta Richter, Oliver Sander, Rebecca Fischer-Betz, Benedikt Ostendorf, Hasan Acar, Ralph Brinks, Matthias Schneider. Policlinic and Hiller Research Unit of Rheumatology, UKD, Heinrich-Heine-University, Duesseldorf, Germany

\subsection{6/lupus-2020-eurolupus. 187}

Background/Purpose Fatigue is the most common symptom in SLE patients with a strong impact on patients' reported quality of life. Previous studies identified possible associations with fatigue with some contradictory results. The aim of this study was to identify additional potentially reversible associations with fatigue to generate targets for future interventions.

Methods Our study population consisted of 234 consecutively recruited SLE (1997 ACR criteria) outpatients from our university hospital based lupus reference centre. We analyzed clinical and demographic data from routine visits, laboratory variables, as well as sleeping disorders, disease perception, coping, social activities and health locus of control using validated questionnaires. We captured fatigue using the Fatigue Severity Scale (FSS). A score of $\geq 4$ points is considered pathological. To assess depression, we used the German CESD depression scale (values $\geq 23 / 60$ points are considered pathological).

Results Our predominantly Caucasian cohort (99.1\%) was mostly female $(87.6 \%)$, with a mean age of 45.3 years $( \pm 13.4[\mathrm{SD}])$ and a mean disease duration of 16.2 years $( \pm 9.5)$. In our cohort, $50.9 \%$ of patients reached a pathological result in the FSS. Depression was significantly associated with fatigue $(\mathrm{p}<0.001)$. Patients with poor health conditions (including sleeping disorders, pain, disease activity and damage) showed significantly more fatigue $(\mathrm{p}<0.01)$. Overall, in $71.4 \%$ of our SLE patients, we could identify at least one potentially reversible association for fatigue (shown in table 1).

\begin{tabular}{|c|c|c|c|c|}
\hline & & No Fatigue & Mild Fatigue & Severe Fatigue \\
\hline Variable & N (\%) & $\begin{array}{l}\text { FSS }<4 \\
\text { points }\end{array}$ & $\begin{array}{l}\text { FSS } 4.0-5.5 \\
\text { points }\end{array}$ & $\begin{array}{l}\text { FSS }=5.6-7.0 \\
\text { points }\end{array}$ \\
\hline $\begin{array}{l}\text { Obesity } \\
\left(\text { BMI }>30 \mathrm{~kg} / \mathrm{m}^{2}\right)\end{array}$ & $\begin{array}{l}27 / 234 \\
(11.5)\end{array}$ & $\begin{array}{l}11 / 115 \\
(9.6)\end{array}$ & $\begin{array}{l}5 / 48 \\
(10.4)\end{array}$ & $11 / 71$ (15.5) \\
\hline $\begin{array}{l}\text { Signs for depression } \\
\text { (CES-D } \geq 23 \text { points) }\end{array}$ & $\begin{array}{l}59 / 209 \\
(28.2)\end{array}$ & $\begin{array}{l}18 / 99 \\
(18.2)\end{array}$ & $\begin{array}{l}14 / 48 \\
(29.2)\end{array}$ & $27 / 71$ (38.0) \\
\hline $\begin{array}{l}\text { Vitamin D deficiency } \\
\text { (25-hydroxyvitamin D } 230 \\
\mathrm{ng} / \mathrm{ml} \text { ) }\end{array}$ & $\begin{array}{l}73 / 213 \\
(34.3)\end{array}$ & $\begin{array}{l}39 / 106 \\
(34.0)\end{array}$ & $\begin{array}{l}14 / 48 \\
(29.2)\end{array}$ & $20 / 71(28.2)$ \\
\hline $\begin{array}{l}\text { Anemia } \\
(\mathrm{Hb}<11.9 \mathrm{~g} / \mathrm{dl})\end{array}$ & $\begin{array}{l}41 / 234 \\
(17.5)\end{array}$ & $\begin{array}{l}17 / 115 \\
(14.8)\end{array}$ & $\begin{array}{l}13 / 48 \\
(27.1)\end{array}$ & $11 / 71$ (15.5) \\
\hline $\begin{array}{l}\text { Hypothyroidism } \\
\text { (TSH >4,2 } \mu \mathrm{Ul} / \mathrm{ml})\end{array}$ & $6 / 225$ (2.6) & $2 / 112(1.7)$ & $2 / 48(4.2)$ & $2 / 71(2.8)$ \\
\hline
\end{tabular}

Conclusion We observed a high prevalence of depressive disorders in our cohort and a significant correlation of depressive status with fatigue. Therefore, we suggest that psychological wellbeing is assessed in everyday clinical practice and treating physicians should react to patients' needs accordingly. Additionally, obesity, anaemia, hypothyroidism and vitamin D deficiency can easily be assessed. Optimizing these factors represent possible targets in order to improve fatigue in SLE patients.

\section{P145 MEMBRANOUS AND PROLIFERATIVE LUPUS NEPHRITIS - ANALYSIS OF A NATIONWIDE MULTICENTRE COHORT}

${ }^{1}$ Filipa Farinha, ${ }^{2}$ Sofia Barreira, ${ }^{3}$ Maura Couto, ${ }^{4}$ Margarida Cunha, ${ }^{5}$ Diogo Fonseca, ${ }^{4}$ Raquel Freitas, ${ }^{6}$ Luís Inês, ${ }^{6}$ Mariana Luís, ${ }^{2}$ Carla Macieira, ${ }^{7}$ Joana Rodrigues, ${ }^{8}$ Bernardo Santos, ${ }^{9}$ Rita Torres, ${ }^{10}$ Ruth Pepper, ${ }^{1}$ Anisur Rahman, ${ }^{4}$ Maria J Santos. ${ }^{1}$ Rheumatology, UCL, London,UK; ${ }^{2}$ Rheumatology, Centro Hospitalar Universitário Lisboa Norte, Lisbon; ${ }^{3}$ Rheumatology, Centro Hospitalar Tondela-Viseu, Viseul; ${ }^{4}$ Rheumatology, Hospital Garcia de Orta, Almada; ${ }^{5}$ Rheumatology, Centro Hospitalar de Vila Nova de Gaia/ Espinho, Espinho; ${ }^{6}$ Rheumatology, Centro Hospitalar Universitário de Coimbra, Coimbra; ${ }^{7}$ Rheumatology, Unidade Local de Saúde do Alto Minho, Ponte de Lima; ${ }^{8}$ Rheumatology, Centro Hospitalar Baixo Vouga, Aveiro; ${ }^{9}$ Rheumatology, Hospital Egas Moniz-CHLO, Lisbon, Portugal; ${ }^{10}$ Nephrology, UCL, London, UK

\subsection{6/lupus-2020-eurolupus. 188}

Background Lupus Nephritis (LN) is one of the most severe manifestations of Systemic Lupus Erythematosus (SLE). We aimed to compare proliferative (PLN), membranous (MLN) and mixed LN regarding clinical and laboratory presentation, and serologic profiles. Previous work suggested that these groups differ in autoantibody profile and complement levels, but those reports mainly originate from singlecentres.

Methods Multicentre observational study, with retrospective analysis of a prospective cohort, using data from the Portuguese registry of rheumatic diseases-Reuma.pt. Patients with biopsy-proven PLN, MLN and mixed LN were included. The first renal biopsy showing one of these classes was considered, for each patient. Groups were compared using Pearson's Chi-Square for categorical variables and One-Way ANOVA or Kruskal-Wallis for numerical variables.

Results 232 patients were included (87\% females; $88.5 \%$ White Europeans). Median follow-up was 7 years (IQR 10.75; maximum 35 years). As seen in table1, the level of proteinuria did not differ between groups; however, MLN patients presented with significantly lower creatinine. Levels of complement were reduced in PLN and mixed LN but were normal in MLN patients, and this difference was statistically significant. Groups also differed regarding the proportion of positivity for anti-dsDNA (higher in PLN) and anti-RNP antibodies (higher in MLN). There was a lower SLEDAI in MLN, probably linked with the lower prevalence of anti-dsDNA antibodies and complement consumption in this group.

Conclusions Our results support previous findings from single-centre studies suggesting that MLN has a different serological profile than PLN, possibly reflecting different pathogenesis. 